\title{
Joggyakorlat
}

PÁL LAJOS*

\section{A munkaszüneti nap és a munkaidő megszervezésének kérdései}

\author{
Questions of Organizing Working Hours in Regard to Public Holidays
}

\begin{abstract}
ABSZTRAKT
A tanulmány azt mutatja be, hogy a munkaszüneti nap sajátos jogi természete milyen dogmatikai hatással van a munkaidő megszervezésére és díjazására. Ez a hatás abban a kettösségben ragadható meg, mely szerint a munkaszüneti nap egyfelöl befolyásolja (csökkenti) a felek kötelességteljesitésének tartamát, de másfelöl hatással van a tényleges teljesités feltételeire is, elsösorban azért, mert munkaszüneti napra munkaidő csak különös feltételek mellett írható elő. De ez a kettősség meghatározza a munkaszüneti nappal kapcsolatos dijazási szabályok dogmatikáját is: a jogalkotó munkabérrel ellentételezi egyrészt a munkaszüneti nap miatt csökkenő munkaidőt, másrészt azt a "teljesitési kellemetlenséget”, amit a munkaszüneti napon történő munkavégzés jelent a munkavállaló számára.
\end{abstract}

Kulcsszavak: munkaidő, munkaidő-beosztás, pihenőidő, müködési rend, munkarend, munkaszüneti nap, vasárnap, munkabér

\begin{abstract}
The study shows the dogmatic effect of the specific legal nature of public holidays on the organization and remuneration of working time. This effect can be seen in the duality that the public holiday affects (reduces) the duration of the parties' performance on the one hand, but also affects the conditions of actual performance, mainly because working time can only be prescribed under special conditions. But this duality also determines the dogmatics of public holiday pay rules: the legislature compensates for the reduced working hours due to public holidays, on the one hand, and the "inconvenience of work" that an employee performs on public holidays, on the other.
\end{abstract}

Keywords: working time, work schedules, rest period, work pattern, public holiday, Sunday, remuneration

* Dr. Pál Lajos, ügyvéd, Pál és Kozma Ügyvédi Iroda, Budapest; megbízott oktató, Károli Gáspár Református Egyetem Munkajogi és Szociális Jogi Tanszék; e-mail: Pal.Lajos@paleskozma.hu. 
A munkaszüneti nap a munkaidő sajátos jogintézménye, befolyásolja mind a teljesítendő munkaidő tartamát, mind a teljesítés konkrét feltételeit, de hatással van a munka díjazására is. Illeszkedése a „munkanap - pihenőnap” dichotómiájába nem egyszerü, az éppúgy felvet fontos és bonyolult dogmatikai kérdéseket, mint gyakorlati alkalmazási problémákat. Ennek ellenére a jogintézménnyel kapcsolatos dogmatikai kérdések feldolgozása a jogirodalomban nem történt meg. A dolgozat erre tesz kísérletet azzal, hogy szándéka szerint elsősorban a munkaszüneti nap jogi természetének kérdését és az ehhez szorosan tapadó problémákat kívánja vizsgálni.

\section{A munkaszüneti nap}

A munkaszüneti nap a munkajogi szabályozás szerint olyan állami, nemzeti vagy vallási ünnepnap, amelyen a munkavállalónak nem kell munkát végeznie. A munkaszüneti napot a munka törvénykönyvéröl szóló 2012. évi I. törvény (a továbbiakban: Mt.) 102. § (1) bekezdése állapítja meg, miszerint munkaszüneti nap: január 1., március 15., nagypéntek, húsvéthétfö, május 1., pünkösdhétfö, augusztus 20., október 23., november 1., december 25-26.

A húsvét- és pünkösdvasárnap nem minősül munkaszüneti napnak, aminek oka, hogy mindkét ünnep olyan napra esik, amikor az általános munkarend szerint egyébként is „munkaszünet”, azaz heti pihenőnap van, és ezért a munkavállalónak már eredendően nem kell munkát végeznie. A tényleges teljesítés szempontjából azonban ezek a napok a munkaszüneti nappal esnek egy tekintet alá, így a munkaidő beosztása vagy rendkívüli munkaidő előírása csak a munkaszüneti napra vonatkozó szabályok szerint megengedett, de a munka díjazására nézve is a munkaszüneti napi teljesítés szabályait kell alkalmazni. ${ }^{1}$

A vallási ünnepek munkaszüneti napként történő törvényi szabályozását egyébként az Alkotmánybíróság is vizsgálta. ${ }^{2}$ Ez jóllehet még a korábban hatályos törvény ${ }^{3}$ rendelkezéseire irányult, ám a határozat megállapításait, mivel az akkor és a ma hatályos törvény szabályozásának lényege azonos, ma is irányadónak tekinthetjük. Az alkotmánybírósági határozat rögzítette, hogy a vallási ünnep munkaszüneti nappá nyilvánításakor az állam alkotmányos kötelezettsége kettős: „Egyrészt nem részesíthet egyetlen vallást kizárólagosan kivételezett elbánásban [...]. Másrészt nem akadályozhatja meg egyetlen - alkotmányos keretek között müködő - vallás híveit sem hitük szabad gyakorlásában."4

A törvény rendelkezéseinek vizsgálata során megállapította, hogy „[a] hatályos magyar szabályozás ellen egyik szempontból sem emelhető alkotmányos aggály". ${ }^{5}$ Ezt azzal indokolta, hogy „[a]z Mt. alapvetően olyan ünnepeket nyilvánít munkaszüneti nappá, amelyeket a társadalom túlnyomó része - vallási meggyőződésétől füg-

\footnotetext{
${ }^{1}$ Mt. 102.§ (4) bekezdés.

2 10/1993. (II. 23.) $A B$ határozat, $A B H$ 1993, 105.

${ }^{3}$ A Munka Törvénykönyvéröl szóló 1992. évi XXII. törvény (a továbbiakban: régi Mt.).

4 10/1993. (II. 23.) AB határozat, $A B H$ 1993, 105.

5 10/1993. (II. 23.) $A B$ határozat, $A B H$ 1993, 105.
} 
getlenül - ünnepnek tart, hozzájuk családi és népszokások kötődnek. [...] Ezekben az ünnepekben ma már a vallási és a világi elemek erősen keverednek. Az, hogy az állam munkaszüneti nappá nyilvánítja némelyiket, nem azok vallási tartalmának szól, hanem a társadalom elvárásain és gazdaságossági megfontolásokon nyugszik. Az állampolgárok többsége ezeket a napokat - azok vallási tartalmával való azonosulás nélkül is - családi körben, hagyományokat követve, vagy akár pihenéssel szereti eltölteni." 6

Annak kapcsán, hogy „a szabályozás nem gátolja-e meg valamely vallás híveit hitük szabad gyakorlásában”, az Alkotmánybíróság azt állapította meg, hogy a törvény „olyan garanciális szabályokat épített ki, melyek lehetővé teszik a munkavállalók számára vallásuk szabad gyakorlását". ${ }^{7}$ Ezt arra a rendelkezésre történő hivatkozással támasztotta alá, amely biztosítja a munkavállaló számára, hogy szabadságának egy részét az általa meghatározott időpontban vegye igénybe. ${ }^{8}$ Ez az Alkotmánybíróság szerint garantálja a vallás szabad gyakorlásához való alkotmányos jogot; azt, hogy „a vallásos munkavállalók [...] minden indokolási kötelezettség nélkül a mások számára kötelező munkanapokon eleget tehessenek vallásuk elöirásainak". ${ }^{9}$

\section{A munkaszüneti nap jogi természete}

A munkajogviszony lényeges sajátossága, hogy a felek kötelességeiket nem általában, hanem időben meghatározott feltételek szerint teljesítik. A munkaidő a munkajogviszony teljesítése tekintetében kettős jellegü, egyrészt mint munkaszerződéses tartalom, másrészt mint konkrét teljesitési feltétel alapvető jelentőségü. A munkaidő tehát egyfelöl meghatározza a felek kötelességteljesítésének szerződéses (elvont) tartamát, másfelöl a teljesítés során a tényleges teljesítés időpontját.

A munka- és pihenőidő, bár egymás ellentétei, mégis szorosan összetartozó jogintézmények, lévén, ami nem pihenőidő, az munkaidő, és fordítva. Ez természetszerủleg igaz a munkanap és a heti pihenőnap vonatkozásában is, azaz valamely naptári nap jellege alapján munkanap vagy heti pihenőnap, és ettől eltérő karaktere a munkaszüneti napnak sincs. Ezért a munkaszüneti napot is munka- vagy pihenönapként kell tekintetbe venni. A munkaszüneti nap - bár rendeltetése a pihenést (is) szolgálja - jogi természetét tekintve nem pihenőidő, hanem annak a naptári napnak az általános munkarend szerinti jogi sorsát osztja, amely napra esik. ${ }^{10} \mathrm{~A}$ munkaszüneti nap tekintetében ugyanaz a kettősség ragadható meg, mint amit fentebb a munkaidő kapcsán kifejtettünk, azaz egyrészt a munkaszüneti nap, ha általános munkarend szerinti munkanapra esik, befolyásolja (csökkenti) a felek kötelességteljesítésének tartamát (a teljesítendő munkaidőt), másrészt hatással van a tényleges teljesítésre is, mert a munkavállaló számára munkaidő munkaszüneti napra csak a

6 10/1993. (II. 23.) AB határozat, $\mathrm{ABH}$ 1993, 105.

7 10/1993. (II. 23.) AB határozat, ABH 1993, 105.

8 Jelenleg ezt a lehetőséget a hatályos Mt. 122. § (2) bekezdése biztosítja.

9 10/1993. (II. 23.) AB határozat, $\mathrm{ABH}$ 1993, 105.

${ }^{10}$ KIss György: Munkajog. Osiris, Budapest, 2005, 162.; BANKó Zoltán-BERKE Gyula-Kıss György: Kommentár a munka törvénykönyvéhez. Wolters Kluwer, Budapest, 2017, 422. 
különös szabályok szerint írható elő. Az adott naptári nap munkaszüneti napi jellege tehát csak a teljesítendő munkaidő tartamának meghatározása, illetve a tényleges teljesítés elrendelése tekintetében releváns, de ennek általános munkarend szerinti karakterét nem módosítja. ${ }^{11}$

Annak ellenére, hogy a munkaszüneti nap megörzi az adott nap általános munkarend szerinti munkanap jellegét, a teljesítendő munkaidő meghatározásakor (az általános munkarend szerinti munkanapra eső) a munkaszüneti napot munkanapként figyelembe venni nem lehet, és ezáltal csökken az adott héten teljesítendő munkaidő tartama, aminek teljesítése nyilvánvalóan más alkalommal sem követelhető. ${ }^{12}$ A munkaszüneti nap így nemcsak a munkavállaló, hanem a munkáltató kötelességteljesítésének tartamát is befolyásolja, azaz a munkaszüneti nap okán mindkét fél teljesítésére irányadó tartam csökken. Ezt a tényt egyébként az sem befolyásolja, hogy a munkavállaló a munkaszüneti napon teljesítésre köteles-e, mert ez már a tényleges teljesités sajátos feltételeivel függ össze.

A munkanap és munkaszüneti nap kapcsán kifejtettek megfelelően irányadók a heti pihenőnap tekintetében is, tudniillik az általános munkarend szerinti heti pihenőnap (szombat, vasárnap) sem veszti el heti pihenőnapi jellegét amiatt, hogy erre a napra egyébként munkaszüneti nap esik. Ezt a napot heti pihenőnapként kell számba venni. Ettől nyilvánvalóan eltérő kérdés az, hogy a munkáltató a munkaidő-beosztás során módosíthatja-e a heti pihenőnapi jelleget, azaz erre a napra oszthat-e be munkanapot. E tekintetben azonban már a munkaszüneti napi munkaidő-beosztás sajátos rendelkezései lesznek az irányadóak, amire a későbbiekben térünk ki.

\section{A munkaszüneti nap tartama}

A törvény szerint a munkaszüneti napra a munkanap tartam-fogalma az irányadó. ${ }^{13}$ Ebből, illetve az előzőekben kifejtettekből egyébként is világosan következik, hogy a munkaszüneti nap tartamát, lévén munkanap, a munkanap tartamával azonos módon kell meghatározni, a munkarend tehát a munka- és munkaszüneti nap tekintetében eltérő tartam-fogalmat nem állapíthat meg. Fontos törvényi megkötés ezen túl, hogy a munkaidő-beosztás szempontjából a reggel hét és este huszonkét óra közötti időszak mindenképp munkaszüneti napnak minősül, amiből következően a megszakítás nélküli huszonnégy óra tartamát a munkarend úgy kell, meghatározza, hogy ebbe a fent írt időszak beletartozzon.

A munkarend szerinti munkanap, illetve munkaszüneti nap tartamának nemcsak a munkaidő megszervezése, hanem a munkavállaló díjazásra való jogosultsága tekintetében is alapvető jelentősége van. A munkaszüneti munkavégzésért járó bérpótlék jogalapját ugyanis e tartam alapján kell megítélni.

\footnotetext{
${ }^{11}$ Ez egyébiránt azonos azzal a tényállással, melyben az adott naptári nap sem veszíti el munkanap jellegét, ha a munkáltató egyenlőtlen munkaidő-beosztás alkalmazása során - az egyes munkanap(ok)ra beosztott többlet-munkaidő „kiegyenlítésének” szándékával - valamely munkanapra munkaidőt egyáltalán nem ír elő, illetve, ha valamely kizáró szabály - például az Mt. 113-114. §-ban foglaltak - okán az adott munkanapra munkaidőt nem oszthat be.

${ }^{12}$ Mt. 93. $§(2)$ bekezdés.

${ }^{13} \mathrm{Mt}$. 87. $\S(2)$ bekezdés.
} 


\section{A munkaidő-beosztás és a munkaszüneti nap}

\subsection{A müködési rend és a munkarend ${ }^{14}$}

A munkaidő megszervezésének hatályos szabályozásával kapcsolatos paradigmaváltás és az ezzel együtt járó dogmatikai pontosítás lényege, hogy a jogalkotó világossá és egyértelművé tette a müködési rend és a munkarend közötti viszonyt. ${ }^{15}$ Eszerint a müködési rend a munkáltató adott tevékenységének sajátosságát, míg a munkarend a munkavállaló munkaidejének beosztására vonatkozó szabályokat jelöli. A korábbi jogi szabályozás terminológiahasználata kétségkívül pontatlan volt, hiszen amikor az általánostól eltérő munkarend alkalmazhatóságának feltételét meghatározta, tartalmát tekintve a munkáltató müködési sajátosságát kodifikálta, emiatt keveredett az ok és okozat.

A müködési rend és a munkaidő megszervezésének szabályozása szorosan öszszefügg, ami egyértelmüen következik abból, hogy a munkáltatói müködés a munkavállaló munkavégzésében nyilvánul meg, csak ennek révén valósulhat meg. Mivel a munkavállalók tevékenységüket kizárólag munkaidőben folytathatják, a munkáltató számára mindenképp olyan munkaidő-megszervezési szabályozás (munkarend és munkaidő-beosztás) szükséges, amely lehetővé teszi számára a sajátos müködéshez igazodó foglalkoztatást.

A jogalkotó kifejezetten meghatározta azon müködési rendek tartalmát, amelyek kapcsán sajátos, az általános munkarendtől eltérő munkaidő-beosztási szabályok (munkarendek) alkalmazását engedi, és a munkáltató csak az ennek való megfelelés esetén alkalmazhatja ezeket. Így tehát elsődlegesen nem a munkáltató diszkrecionális döntésén, hanem a törvényben korlátozott mérlegelési jogán alapul, hogy milyen (az általánostól eltérö) munkarendet alakít ki, aminek mellőzhetetlen feltétele, hogy müködését a törvényben meghatározott feltételek szerint alakítsa ki. A munkáltató céljai elérése érdekében többféle tevékenységet fejt ki, az egyes tevékenységeknek megfelelő, eltérő müködési rendeket alkalmazhat, ezért a működési renddel kapcsolatos feltételeket nyilvánvalóan nem a munkáltató egésze, hanem az egyes munkáltatói tevékenységek tekintetében önállóan kell vizsgálni és adott tevékenységre vonatkozóan lehet alkalmazni a speciális munkarendi szabályokat. A sajátos munkarendi szabályok egyébként olyan tevékenységek tekintetében is alkalmazhatóak, amelyek bár önmagukban nem minősülnek a törvény által meghatározott tevékenységi körbe tartozónak, ám ahhoz szorosan kapcsolódnak, esetleg ezek kifejtése feltétele a sajátos müködési rendbe tartozó tevékenységnek. ${ }^{16}$

Jóllehet a törvény szabályai nem zárják ki, hogy a munkáltató a sajátos müködési feltételeket a kodifikált működési rendek ${ }^{17}$ egy része esetében ne folyamatosan, hanem csak egy meghatározott időszakban teljesítse, ám ez a lehetőség a „rendelte-

${ }^{14}$ Erre nézve részletesebb kifejtés KozMA Anna-LőRINCz György-PÁL Lajos: A munka törvénykönyvének magyarázata. HVG-ORAC, Budapest, 2020, 390-402.

${ }^{15}$ A paradigmaváltást logikailag is indokolja, hogy az általános munkarendtől való eltérés feltétele nyilvánvalóan nem lehet a sajátos munkarend alkalmazása, ahogyan azt a korábbi szabályozás tartalmazta.

16 Ilyen lehet például a raktári vagy karbantartási, hibaelhárítási szolgáltatás.

17 Mt. 90-91. §. 
tése folytán" munkaszüneti naphoz kötődő tevékenység esetén kizárt, hiszen ebben az esetben a törvényi feltételeknek - a müködési rendek sajátos jellege miatt - folyamatosan meg kell felelni. (Egyéb müködési rend esetében azonban nem tartjuk kizártnak, hogy a munkáltató müködése csak az év egy meghatározott időszakában [időszakaiban] feleljen meg a törvény által megszabott müködési rendi feltételeknek.)

Annak, hogy a munkáltató tevékenysége megfelel-e a törvényi feltételeknek, elsősorban azért van jelentősége, mert ez a jogalapja annak, hogy a munkáltató jogszerüen alkalmazzon valamilyen, az általánostól eltérő munkarendi szabályt. Ebből következően ezeket a feltételeket ellenőrzése során vizsgálhatja a hatóság, de a munkavállaló is alapozhatja munkaügyi perben igényét arra, hogy a munkáltató jogellenesen élt valamely munkarendi szabállyal, és ebben az esetben a bíróságnak szükségképpen vizsgálnia kell, hogy a munkáltatói müködés megfelelt-e azoknak a sajátosságoknak, amelyek megalapozhatják az általánostól eltérő munkarendi szabályok alkalmazását. Megjegyezzük, e tekintetben az jelent különös nehézséget, hogy annak megítélése, hogy a munkáltató jogszerüen alkalmazza-e az általánostól eltérő munkaidő megszervezési szabályokat, azaz fennállnak-e e vonatkozásban a működési renddel kapcsolatos sajátos jogalapok, jellemzően csak utólag bírálhatók el.

\subsection{A munkaidő beosztása munkaszüneti napra}

Az uralkodó társadalmi szokások szerint a munkaszüneti napnak a munkavállaló magánélete, családi és társadalmi kapcsolatainak fenntartása szempontjából fokozott jelentősége van. Épp erre tekintettel korlátozza a törvény a munkáltató munkaidő-beosztási jogát: munkaszüneti napra - az általános munkarendi szabályok szerint - munkaidőt nem oszthat be. Ám ne feledjük, azzal, hogy a jogalkotó erre nézve feltételeket szab, valójában a munkáltató munkaszüneti napi tevékenységét korlátozza, hiszen a munkáltatói működés kizárólag a munkavállaló munkavégzése révén nyilvánulhat meg, és emiatt, ha munkaidő munkaszüneti napra nem osztható be, ezen a napon a munkáltató sem képes a müködésre.

A törvény - tekintettel a munkaszüneti napi működést indokolttá, illetve szükségessé tevő munkáltatói működési sajátosságokra - kivételeket állapít meg, így bizonyos esetekben lehetővé teszi a rendes munkaidő beosztását munkaszüneti napra is. Az általánostól eltérő munkarendet lehetővé tevő és kodifikált tevékenységek között jóval szükebb a munkaidő munkaszüneti napra történő munkaidő-beosztást engedő tényállások köre. Ezek

a) a „rendeltetése folytán” munkaszüneti naphoz kötődő,

b) az idényjellegü,

c) a megszakítás nélküli,

d) a társadalmi közszükségletet kielégítő, vagy

e) külföldre történő szolgáltatás nyújtásához - a szolgáltatás jellegéből eredően e napon szükséges munkavégzés,

f) a külföldön történő munkavégzés. 
Tekintettel arra, hogy a szabályozás kimerítő jellegü, a munkaszüneti napon történő tevékenységnek (munkavégzésnek) kizárólag a törvényben megszabott tevékenységek a lehetséges tényállásai, kiterjesztő értelmezésnek nem lehet helye. ${ }^{18}$ A munkaidő-beosztásnak mindig a munkáltatói jognyilatkozat az alapja, így a fenti korlátozások akkor is érvényesülnek, ha a munkavégzésre egyébként a munkavállaló önként jelentkezne.

A fenti tényállások közül részletesen csak azokat elemezzük, amelyek kizárólag munkaszüneti napi munkavégzéshez kötődnek.

\subsubsection{A „rendeltetése folytán” munkaszüneti naphoz kötődő tevékenység}

A törvényi meghatározás szerint a munkáltató vagy a munkakör akkor minősül a munkaszüneti napon is rendeltetése folytán müködőnek, ha

„a) a tevékenység igénybevételére a munkaszüneti naphoz közvetlenül kapcsolódó, helyben kialakult vagy általánosan elfogadott társadalmi szokásból eredő igény alapján, vagy

b) baleset, elemi csapás, súlyos kár, továbbá az egészséget vagy a környezetet fenyegető veszély megelőzése vagy elhárítása, továbbá a vagyonvédelem érdekében kerül sor". 19

Megjegyezzük, a munkáltató müködésén túl a munkakörre való utalás valójában szükségtelen, hiszen a munkaköri feladatok teljesítése és a munkáltató müködése nem választható el, lényegében ugyanarról, nevezetesen a munkáltató működéséröl van szó.

A törvény a munkaszüneti napra történő munkaidö-beosztás, ezzel közvetve a munkáltató e napokon történő müködésének feltételeit két helyen szabályozza. Egyrészt a 101. § (1) bekezdés a) pontja előírja, hogy vasárnapra, „a rendeltetése folytán e napon is müködő munkáltatónál vagy munkakörben" osztható be rendes munkaidő, amit a 102. § (2) bekezdése alkalmazni rendel a munkaszüneti nap tekintetében is. Másrészt értelmezi, hogy a munkáltató (vagy a munkakör) mikor minősül a munkaszüneti napon is rendeltetése folytán müködőnek. ${ }^{20}$

A törvény a munkaszüneti napi működés feltételeit, azaz a müködés „rendeltetését" két fordulattal szabályozza.

Egyrészröl a munkáltató (vagy a munkakör) akkor minősül munkaszüneti napon is rendeltetése folytán működőnek, ha a munkáltató müködésére „,baleset, elemi csapás, súlyos kár, továbbá az egészséget vagy a környezetet fenyegető veszély megelözése vagy elháritása, továbbá a vagyonvédelem érdekében kerül sor". ${ }^{21} \mathrm{El}$ tekintve attól, hogy ezek a feladatok valójában semmi módon nem kötődnek a munkaszüneti nap rendeltetéséhez, ez esetben ugyanis sokkal inkább arról van szó, hogy ezeket a tevékenységeket folyamatosan ki kell fejteni, vita a gyakorlatban e

\footnotetext{
18 EBH 2010.2157.

${ }^{19}$ Mt. 102. § (3) bekezdés.

${ }^{20}$ Mt. 102. $\S(3)$ bekezdés.

${ }^{21}$ Mt. 102. $\S(3)$ bekezdés $\left.b\right)$ pont.
} 
rendelkezés értelmezése kapcsán nem merült fel. Talán csak a „súlyos kár” megelözésével, illetve elhárításával kapcsolatban érdemes utalnunk arra, hogy e vonatkozásban a megszoritó értelmezést tekintjük helyesnek. Eszerint a fenyegető súlyos kárnak nem közvetlenül a munkáltató gazdálkodásával, hanem általános müködésével kell összefüggésben állnia. Így a megrendelői igények teljesítésének elmaradása kapcsán fizetendő kártérítés bizonyosan nem alapozhatja meg e napokon a munkavégzés elrendelését, ám a munkáltató vagyontárgyait fenyegető veszély (például árvíz vagy súlyos müszaki hiba) vélhetően már igen.

Másrészről a munkaszüneti napra történő munkaidő-beosztásra az adhat jogalapot, ha „a [munkáltató által nyújtott] tevékenység igénybevételére a munkaszüneti naphoz [vasárnaphoz] közvetlenül kapcsolódó, helyben kialakult vagy általánosan elfogadott társadalmi szokásból eredő igény" van. ${ }^{22}$ Ám ez a fordulat az előzőekhez képest már sokkal inkább ad vitára lehetőséget. Látható, a fogalommeghatározás nem volt szükségtelen, hiszen ha csak önmagában a munkaidő beosztására vonatkozó tételes jogi szabályt olvassuk, miszerint munkaszüneti napra „a rendeltetése folytán e napon is müködő munkáltatónál vagy munkakörben" osztható be rendes munkaidő, kialakulhat némi bizonytalanság. ${ }^{23}$ Mégpedig azért, mert a nem egészen egyértelmű megfogalmazásból kétséget kizáróan nem tünik ki, hogy valójában nem a munkáltatói müködés, hanem a munkaszüneti nap rendeltetéséröl van szó. (Ellentétben a b) pont szerinti fordulattal, amely, mint arra fentebb hivatkoztunk, sokkal inkább a munkáltatói tevékenységre, mint e ,jeles” napok rendeltetésére utal.) A munkáltatói tevékenység sajátossága (rendeltetése) ez esetben tehát csak abban áll, hogy a munkáltatói müködés a munkaszüneti nap rendeltetésének (funkciójának, céljának) megvalósulását szolgálja, a munkáltatói szolgáltatás jellege ehhez szorosan kötődik, és ez az, ami az e napon történő munkáltatói müködés lehetöségét, szükségességét, és ennek alapján a rendes munkaidő beosztásának jogát megalapozza.

A munkaszüneti nap rendeltetésének megítélésünk szerint helyes értelmezés mellett a pihenést, a szórakozást, a kikapcsolódást, a hitéleti tevékenységbe, illetve a nemzeti megemlékezésbe való bekapcsolódást kell tekinteni. A munkáltatói múködésnek tehát ezekhez kell szorosan kapcsolódnia, ezek megvalósulását kell lehetővé tennie. Hangsúlyozzuk, a munkáltató müködését megalapozó társadalmi szokásnak közvetlenül a munkaszüneti nap rendeltetéséböl kell fakadnia, ezért önmagában valamely elterjedt magatartás, aminek nincs köze e napok rendeltetéséhez, a rendes munkaidő beosztására, lényegében a munkáltatói működésre jogalapot nem teremthet. $E$ tekintetben iránymutató ítélkezési gyakorlat nem igazán áll rendelkezésre, de a Kúria még a régi Mt. hatálya alatt a vasárnap rendeltetésével kapcsolatban ítéletében kimondta, hogy „a fövárosi bevásárlóközpontban található ruházati üzlet az elmúlt évek során a vásárlási szokások lényeges átalakulása folytán vasárnap rendeltetése folytán müködőnek minősül”. ${ }^{24} \mathrm{Az}$ indokolás szerint: „[a] munkaügyi biróság e körben helyesen értékelte, hogy a felperes üzlete fövárosi be-

\footnotetext{
22 Mt. 102. § (3) bekezdés a) pont.

${ }^{23}$ Mt. 101. $\S(1)$ bekezdés a) pont.

${ }^{24} \mathrm{BH} 2013.225$.
} 
vásárlóközpontban található, ezért e ténynek és nem elsődlegesen az üzlet profiljának van jelentősége. Helytállóan érvelt a felperes [munkáltató] azzal, hogy az elmúlt évek során a vásárlási szokások lényegesen átalakultak és a társadalmi igények jelentősen megváltoztak, melyet nem lehet értékelés nélkül hagyni."25

Álláspontunk szerint mind az érdemi döntés, mind annak indokolása fölöttébb vitatható. Szem elöl téveszti ugyanis azt, amire fentebb már utaltunk: a társadalmi szokásokat a vasárnap, illetve a munkaszüneti nap rendeltetése alapján kell megítélni, azaz a szokásoknak ezek rendeltetéséböl kell fakadniuk. Az az érvelés, pontosabban az ebböl levont következtetés, miszerint „,az elmúlt évek során jelentős társadalmi igény alakult ki a bevásárlóközpontokban a vasárnapi vásárláshoz", álláspontunk szerint téves. Már maga az is kérdés, hogy ebben az esetben valóban társadalmi szokásról beszélhetünk-e, vagy csak vásárlói magatartásról. Az azonban szerintünk nem kétséges, hogy a Kúria által szokásként felfogott magatartás nem a vasárnap rendeltetéséből fakad, itt legfeljebb arról lehet szó, hogy a vásárlási szokások átalakultak, ám ez nem a vasárnaphoz kötődő szokások változása, hanem az üzletek vasárnapi nyitvatartása által megteremtett lehetőségen alapul. Annak „perdöntő” jellegét sem igazán látjuk, mennyiben befolyásolja a kérdés megítélését, hogy a konkrét tényállás szerint „fővárosi bevásárlóközpontban” lévő üzletröl volt szó.

\subsubsection{A társadalmi közszükségletet kielégítö, vagy külföldre történő szolgáltatás nyújtásához - a szolgáltatás jellegéböl eredően - e napon szükséges munkavégzés}

A törvény ebben a tényállásban is a munkaszüneti napra történő rendes munkaidő beosztásának lehetőségét teremti meg. ${ }^{26}$ Ez esetben szintén két fordulatot tartalmaz, de mindkét tényállás tekintetében közös, hogy a munkavégzés az adott napon nem mellőzhető.

A „társadalmi közszükségletet kielégítő” munkáltatói tevékenység mint jogalap egyébként más tényállásokban is megjelenik. Kétségkívül ilyen a megszakítás nélküli tevékenység, de ilyennek tekinthetjük a 102. § (3) bekezdés $b$ ) pontjában írt fordulatot is. Ebben az esetben tehát olyan munkáltatói tevékenységről lehet szó, ami bár nem tartozik az elöbb említett két esetkörbe, de a szolgáltatás valamely közszükséglet kielégítésére irányul, ennek folyamatos igénybevétele közérdek.

A külföldre történő szolgáltatás nyújtásának értelmezése okoz némi bizonytalanságot a gyakorlatban. E tekintetben nem arról van szó, hogy a munkáltató által elöállított valamely terméket külföldre kell szállítani, amit valamely külföldi megrendelő felhasznál. A felhatalmazás kizárólag olyan tevékenység folytatására adhat jogalapot, amely tartalmát tekintve valóban szolgáltatásnyújtás és magát a szolgáltatást veszik külföldön igénybe. llyenek tipikusan az informatikai helpdesk vagy SSC szolgáltatások, de e körbe tartozhat például a gyorsposta tevékenység is. A szolgáltatásnyújtás egyébként történhet akár kül-, akár belföldön, a meghatározó az, hogy az igénybevétel külföldön történjen.

\footnotetext{
${ }^{25} \mathrm{BH} 2013.225$.

${ }^{26}$ Mt. 101. $\S(1)$ bekezdés $g$ ) pont.
} 


\subsubsection{A külföldön történö munkavégzés}

Abban az esetben, ha a munkavállaló a munkavégzési kötelességét külföldön teljesíti és a rá irányadó hazai teljesítési szabályok szerint munkaszüneti napon rendes munkaidő nem osztható be, az észszerü müködés és gazdálkodás követelményére tekintettel a törvény megengedi, hogy a munkáltató a külföldi munkavégzés tartama alatt e napokon rendes munkaidőt osszon be. ${ }^{27}$

\subsection{Rendkívüli munkaidő elrendelése}

Jól látható a munkaszüneti nap sajátos jellege a rendkívüli munkaidő elrendelése tekintetében is. A törvény ugyanis a rendkívüli munkaidő elöírását az általánoshoz képest szigorúbb feltételekhez köti. Rendkívüli munkaidő csak

a) a rendes munkaidőben e napon is foglalkoztatható munkavállaló számára, vagy

b) baleset, elemi csapás, súlyos kár, az egészséget vagy

c) a környezetet fenyegető közvetlen és súlyos veszély megelőzése, elhárítása érdekében rendelhető el. ${ }^{28}$

\subsection{A heti pihenőnap (pihenőidő) beosztása és a munkaszüneti nap}

Az általánostól eltérő munkarend szerint foglalkoztatott munkavállaló esetében felmerülhet, hogy a munkaszüneti nap a munkaidö-beosztás szerinti heti pihenönapra esik. Ekkor a kérdés az, hogy a heti pihenőnap megörzi, megőrizheti-e ilyen jellegét. Ennek eldöntése során valójában annak van jelentősége, hogy a munkáltató a munkaszüneti napra írhat-e elő munkavégzési kötelességet, vagy sem. Akkor, ha a munkáltató az Mt. 102. § alapján munkaszüneti napra munkaidőt írhat elő, nem kétséges, hogy jogosult munkaszüneti napra is heti pihenőnapot (pihenőidőt) beosztani. Ám, ha a munkaidő beosztása munkaszüneti napra nem megengedett, erre a napra heti pihenőnap sem osztható be. Könnyen belátható, hogy a munkavállaló olyan napon, amelyen valamely különös szabály okán (munkaszüneti nap) munkavégzési kötelessége nincs, más jogcímen, így heti pihenőnap jogcímén sem mentesíthető. Ebből következően ilyen esetben az a naptári nap, amely munkaszüneti napnak minősül - függetlenül a munkaidő-beosztástól - heti pihenőnap címén nem vehető számításba. Megjegyezzük, ha a munkáltató általánostól eltérő munkarend esetén az általános munkarend szerinti pihenőnapra munkanapot oszt be és ez munkaszüneti napnak minősül, e nap munkanap karaktere megmarad, de munkavégzés elöírása csak a törvény különös szabályai esetén lehetséges.

A fentiektöl eltérő a helyzet jogi megítélése, ha a munkaszüneti nap az általános munkarend szerinti heti pihenőnapra (szombat, vasárnap) esik, amint fentebb írtuk, ebben az esetben az adott nap megőrzi heti pihenőnap jellegét.

\footnotetext{
${ }^{27}$ Mt. 101. $§(1)$ bekezdés $h$ ) pont.

${ }^{28}$ Mt. 108. $\S(3)$ bekezdés.
} 


\section{A munkaszüneti nappal összefüggő díjazási szabályok}

A munkaszüneti napnak jelentős hatása van a munkavállaló díjazására is. Ebböl a szempontból meghatározó jelentőségű a munkaszüneti nap kettős jellege, amire fentebb már utaltunk. A díjazási szabályokat ezért aszerint kell tárgyalnunk, hogy a munkaszüneti nap a teljesítendő munkaidő tartamára vagy a tényleges teljesitésre van-e hatással.

Az általános munkarend szerinti munkanapra eső munkaszüneti nap a teljesítendő munkaidő tartamát csökkenti, és ha ennek következtében a munkavállaló munkabére is csökken, a törvény a „keresetveszteség” kompenzációját írja elö. A munkaszüneti nap okán kizárólag az eseti alapú elszámolással díjazott munkavállaló munkabére csökkenhet.

A havibéres munkavállaló munkabére ugyanis átalány jellegü, hiszen a havibér összege független a munkavállaló által, az általános munkarend szerint teljesítendő munkaidő tartamától, így az ilyen munkavállalót keresetveszteség a munkaszüneti nap okán nem érheti. Semmi ok sincs arra, hogy a munkavállaló olyan hónapban, amikor a munkaszüneti nap miatt egyébként csökken a teljesítendő munkaideje, a havi béréhez képest többlet-díjazásra legyen jogosult.

Az óra- vagy teljesítménybéres munkavállaló elszámolása azonban, közvetve vagy közvetlenül, de összefügg az általa teljesített munkaidővel, ezért az általa elérhető (megkereshető) munkabér összegét befolyásolja a teljesítendő munkaidő tartama. ${ }^{29} \mathrm{~A}$ „keresetveszteség” kiegyenlítése érdekében a törvény elöírja, ha az általános munkarend szerinti munkanapra eső munkaszüneti nap miatt az általa teljesítendő munkaidő csökken, óra- vagy teljesítménybérezés esetén a szerződés szerinti napi munkaidővel azonos tartamra járó távolléti díj illeti meg a munkavállalót. ${ }^{30} \mathrm{~A}$ munkavállaló távolléti díjra való jogosultsága tehát független a tényleges munkaidő-beosztásától, ennek kizárólagos jogalapja, hogy az általa teljesítendő munkaidő csökken, lévén a munkaszüneti nap az általános munkarend szerinti munkanapra esik. A távolléti díj számításának alapja a szerződés szerinti napi munkaidő.

Fontos hangsúlyozni, hogy ebben az esetben nem a munkaszüneti napra járó dijjazás szabályairól van szó. Ez a díjazás kizárólag a munkaszüneti nap miatt csökkenő munkaidő okán bekövetkező keresetveszteséget kompenzálja, és teljességgel független attól, hogy a munkavállaló munkaszüneti napon végez-e munkát, vagy sem.

Különös szabály irányadó, ha a munkavállaló a munkaszüneti napon keresőképtelen, ekkor nem a távolléti díjára, hanem a távolléti díj hetven százalékára jogosult, illetve nem illeti meg a távolléti díj, ha keresőképtelenségére tekintettel társadalombiztosítási ellátásban (táppénzben vagy baleseti táppénzben) részesül. Ez a díjazás bár mértékét tekintve megfelel a betegszabadság mértékének, a két díjazás jogalapja jelentősen eltér. A munkaszüneti nap kapcsán már elmondtuk: a díjazás rendeltetése, hogy megóvja a munkavállalót a munkaszüneti nap következtében csökkenő teljesítendő munkaidő miatti munkabérveszteségtől, így, ha a munkavállaló a mun-

\footnotetext{
${ }^{29} \mathrm{BH}$ 1977.515., BH 1983.465.

${ }^{30}$ Mt. 146. $\S(3)$ bekezdés $d$ ) pont.
} 
kaszüneti napon keresőképtelen, vesztesége csak a távolléti díj hetven százaléka, illetve, ha táppénzt vagy baleseti táppénzt kap, veszteség egyáltalán nincs. A jogalkotó tehát abból indul ki, ha a munkaszüneti nap miatt a munkaidő nem csökkenne és a munkavállaló munkát végezhetne, keresetveszteség sem érné. A munkaidőcsökkenés, pontosabban az emiatti bérveszteség kompenzálása a távolléti díj fizetése esetén absztrakt jellegü, hiszen a „veszteség” pontos összege nem határozható meg. Keresőképtelenség esetén pedig abból indulunk ki, ha a munkaszüneti nap munkanap lenne, a munkavállaló a betegszabadságra vagy a táppénzre vonatkozó szabályok szerint kapna díjazást, tehát keresetvesztesége vagy a betegszabadság összegével egyezik meg (a távolléti díj hetven százaléka), vagy a táppénzre való jogosultság miatt egyáltalán nincs.

A fentiektől eltérő, alapvetően más jogalapon nyugszik a munkaszüneti napon tejesített munkavégzés díjazása. Ennek indoka, annak a „kellemetlenségnek” az ellentételezése, amit a munkaszüneti napon történő munkavégzés a munkavállaló számára jelenthet. (Ez rendeltetését tekintve roppant hasonló a vasárnapi munkavégzés pótlékához.)

A munkavállaló, ha munkaszüneti napon rendes munkaidőt teljesít, a részére egyébként járó munkabéren túl, száz százalék bérpótlékra jogosult. Ez a díjazás már független attól, hogy a munkaszüneti nap csökkenti-e a munkaidöt, emiatt érheti-e a munkavállalót keresetveszteség, vagy sem. A bérpótlék tehát akkor is jár, ha a munkaszüneti nap egyébként vasárnapra esik vagy a munkavállaló havi béres. E díjazás jogalapját tekintve semmi összefüggésben nincs a 146. $\S(3)$ bekezdés $d$ ) pontja, illetve a 146. $§(4)$ bekezdése szerinti díjazással.

A munkavállaló, ha a beosztás szerinti munkaideje munkaszüneti napon van, és keresőképtelenség okán munkát nem tud végezni, az általános szabályok szerint jogosult betegszabadságra vagy táppénzre. Utalunk újfent arra, hogy ez nem érinti a 146. § (4) bekezdése szerinti díjazás jogalapját.

A bérpótlék megilleti a munkavállalót a húsvét- vagy pünkösdvasárnap teljesített munkaidő esetén is. A bérpótlékra való jogosultságot, már utaltunk rá, nem érinti, hogy a munkaszüneti nap vasárnapra esik-e. A munkaszüneti napi, illetve a vasárnapi bérpótlék egymást kizárja, ezért, ha a munkaszüneti nap vasárnapra esik és a munkavállaló munkát végez, számára a munkaszüneti pótlék jár.

A munkaszüneti napra elrendelt rendkívüli munkaidőben végzett munka a munkaszüneti napi pótlékra való jogosultságot nem érinti, a munkavállaló számára ugyanis azt a munkabért kell elszámolni, ami őt rendes munkaidőben történő munkavégzés esetén megilletné, és ezen túl jár számára annak ellenértéke is, hogy a munkavégzésre rendkívüli munkaidőben került sor. A munkaszüneti napon teljesített rendkívüli munkaidő pótlék mértéke száz százalék.

\section{A munkaszüneti napok körüli munkarend meghatározása}

Sajátos, a törvény szerinti általános munkarendtől eltérő tényállás a munkaszüneti napok körüli munkarend. Régi „hagyománya” a magyar munkajogi szabályozásnak, hogy az illetékes miniszter az általános munkarend munkaszüneti napok 
miatti módosítását évenként rendeletben szabályozza. ${ }^{31}$ Ennek lényege, hogy a jogszabály az adott heti általános munkarend szerinti munkanapot heti pihenőnappal, illetve a heti pihenőnapot munkanappal cseréli fel, tartalmát tekintve az adott hétre irányadó általános munkarendet módosítja. Erre szokás szerint akkor kerül sor, ha a munkaszüneti nap keddre vagy csütörtökre esik, a változtatás célja nyilvánvaló: a heti pihenőnapok közé ne „ékelödjön” egy munkanap, ami azért lehet indokolt, mert a naptár szerinti helyzet a munkáltatói müködés szempontjából okozhat nehézséget, de a munkavállaló számára is kedvezöbb, ha rendelkezésre állási kötelessége több napon át megszakítás nélkül szünetel.

A miniszteri szabályozás egyidejüleg mindig két - jellemzően egymást követő naptári hét általános munkarendjét érinti. A módosítás szerint azon a héten, amikor a munkaszüneti nap van, a hétfőt vagy a pénteket munkanap helyett heti pihenönapnak, míg a másik héten a szombatot heti pihenőnap helyett munkanapnak kell tekinteni. Törvényi megkötés, hogy mindkét hétre vonatkozó változtatásnak azonos hónapon belül kell lennie, továbbá a változtatás során kizárt a vasárnap munkanappá nyilvánítása.

A vasárnap munkanappá nyilvánításának tilalmára vonatkozó rendelkezés alkotmányosságát az Alkotmánybíróság is vizsgálta, mégpedig abból a szempontból, hogy ez „nem sérti-e az állampolgári egyenlőség elvét azzal, hogy diszkriminál az egyes vallások, és azok hívei között". ${ }^{32}$

Ennek kapcsán megállapította, hogy „[a] vasárnapi pihenönap szokása a hagyományokon alapul, s ez ma már a világ nagy részén egységes gyakorlat; kétségtelen eredeti vallási tartalma, azonban ezt már rég elvesztette; jelenlegi, kimondottan világi jellegű célja az, hogy az állampolgárok számára egységes heti pihenőnapot biztosítson. Ehhez járult [...] s nem vallási megfontolások eredményeként a szombati pihenőnap általánossá válása [...]. Ez azonban a tényen nem változtat, hogy a munkajogi szabályozás egyetlen egységes heti pihenőnap biztositására törekszik a lehetöségek határain belül. Az ünnepek körüli munkaidö-beosztás megváltoztatására - a beadvány állitásával ellentétben - a munkaügyi miniszter korlátozott jogosítványokkal rendelkezik a társadalmi elvárások és a gazdaságossági szempontok által kellöen indokolt esetben." 33

Általános munkarendnek az adott héten a rendelet szerinti előírás minősül, tehát a szabályozással érintett héten általános munkarendként ezt kell irányadónak tekinteni. A miniszter által megállapított általános munkarendnek közvetlenül a teljesítésre van kihatása, ami azt jelenti, hogy az általános munkarend szerint foglalkoztatott munkavállaló munkaidő-beosztása a rendelet szerint alakul. Az általánostól eltérő munkarend esetében azonban a rendeletet nem szükséges alkalmazni, mert a hatálya erre nem terjed ki. Ezért a munkáltató a miniszter által megállapított általános munkarendtől az általános szabályok szerint eltérhet. Arra azonban rá kell mutatni, hogy az eltérés kizárólag egyenlőtlen munkaidő-beosztás alkalmazása alapján lehetséges.

\footnotetext{
31 Mt. 102. $§(5)$ bekezdés.

32 10/1993. (II. 23.) AB határozat, $A B H$ 1993, 105.

33 10/1993. (II. 23.) $A B$ határozat, $A B H$ 1993, 105.
} 
A miniszteri rendelet szerinti általános munkarendnek azonban van közvetett hatása is. Utaltunk már arra, hogy az általános munkarend egyik dimenziója, hogy ennek alapján kell meghatározni a teljesítendő munkaidő tartamát, ami a konkrét teljesítéstől (munkarendtől) függetlenül valamennyi munkavállaló esetében irányadó, ezért a rendelettel érintett héten a teljesítendő munkaidő tartamának meghatározásakor az általánostól eltérő munkarendben foglalkoztatott munkavállaló esetében is a rendelet szerinti munkarend alapján kell eljárni.

A fentiekből következően a havibér arányos részének kiszámításakor is a miniszter által megállapítottat kell általános munkarendként alapul venni. ${ }^{34}$ Így, ha a havibéres munkavállaló munkajogviszonya azt követően szünik meg, amikor a rendelet alapján a munkanapok száma megnövekedett, de még a több heti pihenőnapot tartalmazó hét teljesítésére nem került sor, a havibér arányos részének megállapításánál hat munkanapot kell figyelembe venni, de a munkavállaló rendkívüli munkaidő szerinti díjazásra nem lesz jogosult. Míg fordított esetben a havibér arányos részét négy munkanap alapján kell kiszámítani.

\section{7. Összegzés}

Az kívántuk bemutatni, hogy munkaszüneti nap sajátos jogi természete dogmatikai hatással van a munkaidő megszervezésére és díjazására is. Ez jól láthatóan abban a kettősségben ragadható meg, mely szerint a munkaszüneti nap egyfelöl befolyásolja (csökkenti) a felek kötelességteljesítésének tartamát, de másfelöl hatással van a tényleges teljesítés feltételeire is, mégpedig annak okán, hogy munkaszüneti napra munkaidő csak különös feltételek mellett írható elö. Fontos hangsúlyozni, hogy a munkaidő munkaszüneti napra történő beosztásának munkatörvényi szabálya paradigmaváltás eredménye: ennek alapján vált ugyanis egyértelművé, hogy kizárólag a munkáltatói tevékenység - jogalkotó által elismert (kodifikált) - sajátossága alapozhatja meg a munkaszüneti napon történő müködést és ennek alapján a munkaidő beosztásának munkáltatói jogát.

Ez a kettősség azonban meghatározza a munkaszüneti nappal kapcsolatos díjazási szabályok dogmatikáját is: a jogalkotó munkabérrel ellentételezi egyrészt a munkaszüneti nap okán csökkenő munkaidőt, másrészt azt a „teljesítési kellemetlenséget", amit a munkaszüneti napon történő munkavégzés jelent a munkavállaló számára.

${ }^{34}$ Mt. 136. § (3) bekezdés. 